Proc. Estonian Acad. Sci. Geol., 2000, 49, 2, 85-103

\title{
LOWER SILURIAN STRATIGRAPHY OF THE TIMAN-NORTHERN URAL REGION AND EUSTATIC FLUCTUATION
}

\author{
Sergej V. MELNIKOV ${ }^{\mathrm{a}}$ and Valentina A. ZHEMCHUGOVA ${ }^{\mathrm{b}}$
}

a Timan-Pechora Scientific and Research Centre, Pushkinskaya 2, 169400 Ukhta, Komi Republic, Russia; tpsrc@server.ru

b Technical University, Pervomajskaya 13, 169400 Ukhta, Komi Republic, Russia

Received 10 January 2000, in revised form 17 March 2000

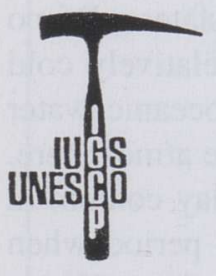

IGCP Project 406

Circum-Arctic Lower-

Middle Palaeozoic

Vertebrate Palaeontology

and Biostratigraphy

Abstract. This article is an attempt to correlate the Lower Silurian strata of the Timan-northern Ural region with the general international stratigraphic scale and to describe some global Silurian climatic events recognized in this area. The study of the distribution of Silurian faunas in the Kozhym River section (Subpolar Urals) allowed definition of 25 datums marked by the appearances and/or disappearances of taxa. Facies and sequence-stratigraphical analysis of strata resulted in identification of six sequences. Relative sea level fluctuations were determined. Considering the succession of sea level and faunal changes in early Silurian strata, six shallow shelf episodes were distinguished. On the basis of the assumption that the eustatic changes in sea level and climatic oceanic episodes (Jeppsson 1990. J. Geol. Soc. London, 147, 663-674) are caused by plate tectonics oceanic and shelf episodes were correlated. The correlation shows that the Lower Dzhagal Substage is Rhuddanian and the upper Dzhagal Substage Aeronian in age, the Filipp"el' Stage and the lower part of the Sed"el' Stage correspond to the Telychian, and the upper part of the Sed"el' Stage to the Sheinwoodian.

Key words: biostratigraphy, sequence stratigraphy, eustasy, oceanic episodes and events, Lower Silurian, Timan-northern Ural region, Russia.

\section{INTRODUCTION}

The revolution in geosciences in the 1960s and 1970s raised geological investigations to a new level. It requires some global generalizations, synthesis of the data about the evolution of the sedimentation and changes in biotas following the intercontinental high-resolution correlations based on detailed regional 
biostratigraphical schemes. All zonal schemes, however, are based on the distribution of a particular group of fossils and as a rule characterize specific environments. For example, graptolites are preserved in adequate numbers only in the strata formed in the open sea deep-water environments. In shallow-water shelf deposits graptolites are very rare. Conodonts are common in both the deepwater and shallow-water environments, but the correlation of these assemblages is complicated due to their different compositions. The benthic fauna is very sensitive to environmental changes. As the biostratigraphical method is still the leading one in stratigraphy, correlation of zonations based on different fossils is very important. However, it is very complicated due to the above reasons, and therefore many scientists continue to look for levels of global bio- and geoevents traceable in all environments of the world.

An attempt to recognize such events was made by L. Jeppsson (Jeppsson 1988, 1994; Aldridge et al. 1993; Jeppsson et al. 1995), who established a succession of episodes and events in the Llandovery and Wenlock. His studies were based on a model which relates variations in sedimentation within oceanic depressions and changes in the composition and abundance of biota with alterations in climate and atmospheric $\mathrm{CO}_{2}$ concentration (Jeppsson 1990). Within his model, two major types of cyclically alternating oceanic states - Primo and Secundo episodes - were recognized. A Primo episode is a relatively cold period showing an increase in the $\mathrm{CO}_{2}$ solubility in cold bottom oceanic water and resulting in extraction of a considerable amount of $\mathrm{CO}_{2}$ from the atmosphere. During a Primo episode carbonate deposition is reduced and the clay content in the carbonates increases. A Secundo episode is a relatively warm period when dense saline water flows down from the shelves into oceanic depressions (Nesov 1990), bringing heat and causing the invasion of warm-water species into the deep-water basinal areas. The increase in the temperature of the bottom oceanic water results in the decrease in $\mathrm{CO}_{2}$ solubility and the increase in atmospheric $\mathrm{CO}_{2}$ concentration, and hence, in the expansion of the area of pure carbonate sedimentation, characterized by rich and diverse benthic communities.

Our conclusions are based on the studies of the facies succession reflecting eustatic fluctuations. We suppose that the oceanic episodes proposed by Jeppsson as well as sea level fluctuations are the result of cyclicity in plate tectonics whose activity determined the volume of oceanic depressions (sea level fluctuations), the plate locations (climatic changes in certain regions), and volcanic activity (variation in $\mathrm{CO}_{2}$ concentration in the atmosphere) (Mel'nikov \& Zhemchugova 1999).

\section{STRATIGRAPHY}

During prospecting for oil and gas till the early 1990s numerous data on the lithology and stratigraphy of the Timan-northern Ural region were collected (Fig. 1). At present, two officially accepted stratigraphic schemes are available 


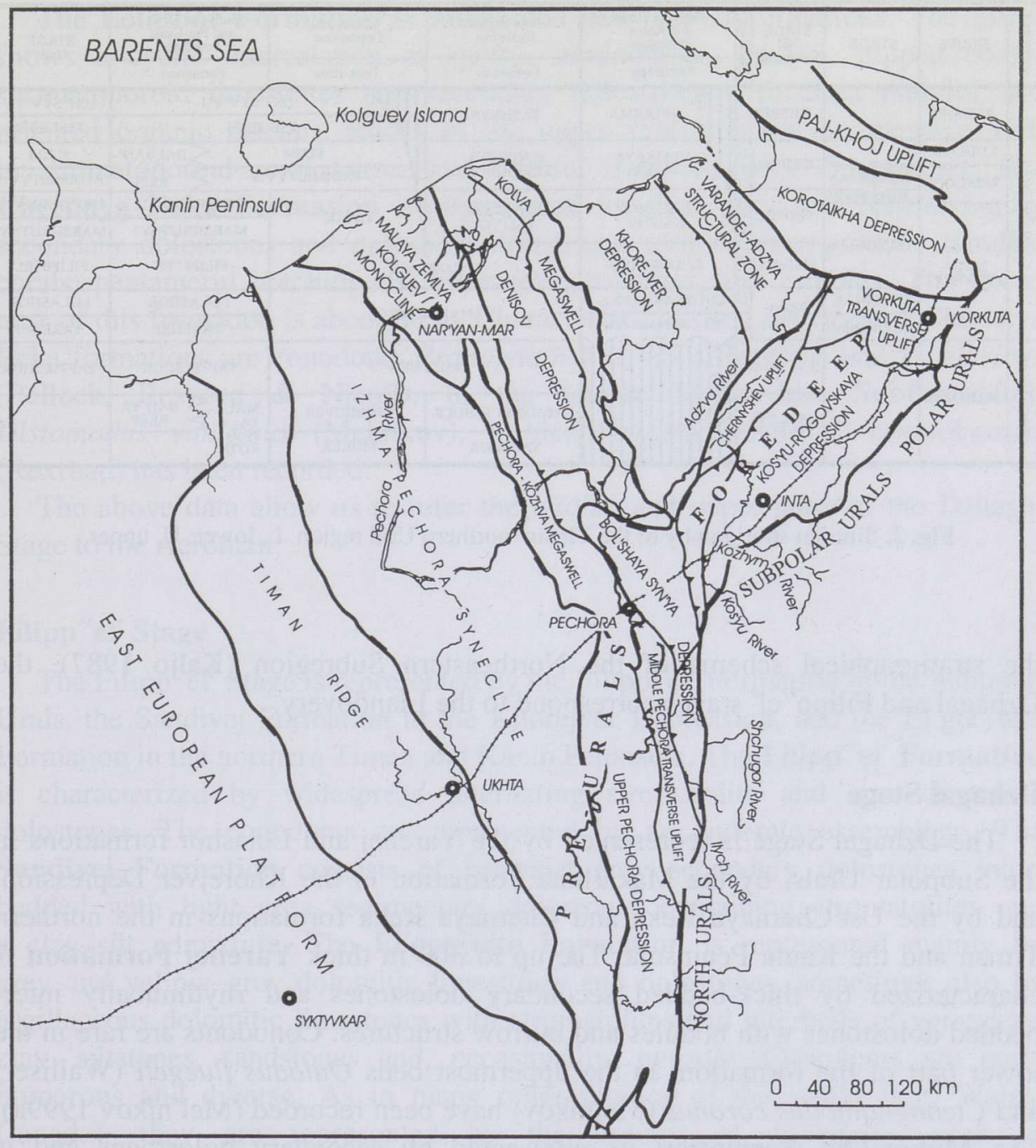

Fig. 1. Generalized map of tectonic structures in the Timan-northern Ural region.

for this region. Despite the evident unity of the sedimentary basin, the schemes for the Northeastern Subregion of the East European Platform (Timan-Pechora region) and the Urals were elaborated independently at different times. The Ural sequence (outcrops) has for a long time been considered as a regional standard and has been studied in a considerably greater detail than drill cores from the Northeastern Subregion. The quality of the cores was highly variable depending upon core recovery, quality of logging, and particular tasks of drilling. Nevertheless, the analogues of all major stratigraphical subdivisions described in the Ural sequence were recognized also in the Northeastern Subregion (Fig. 2). In 


\begin{tabular}{|c|c|c|c|c|c|c|c|c|}
\hline \multirow{2}{*}{ 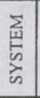 } & \multirow[t]{2}{*}{ SERIES } & \multirow[t]{2}{*}{ STAGE } & \multirow{2}{*}{\begin{tabular}{c|c|c|} 
STAGE & No \\
NE \\
Subregion
\end{tabular}} & $\begin{array}{l}\text { Northern Timan } \\
\text { and Kanin } \\
\text { Peninsula }\end{array}$ & \multirow[t]{2}{*}{$\begin{array}{l}\text { Iahma-Pechora } \\
\text { Syneclise }\end{array}$} & $\begin{array}{l}\text { Khorejver } \\
\text { Depression }\end{array}$ & $\begin{array}{l}\text { Subpolar Urals } \\
\text { and Pre-Urals } \\
\text { Foredeep }\end{array}$ & \multirow[t]{2}{*}{$\begin{array}{l}\text { STAGE } \\
\text { Urals }\end{array}$} \\
\hline & & & & Formation & & Formation & Formation & \\
\hline \multirow{9}{*}{ 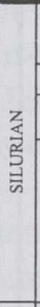 } & \multirow{2}{*}{ PŘIDOLI } & & \multirow{2}{*}{ GREBEN' } & \multirow{2}{*}{ EPTARMA } & \multirow{2}{*}{ PASHNYA } & \multicolumn{2}{|c|}{ UST'SYV'YU } & UST'SYV'YU \\
\hline & & & & & & \multicolumn{2}{|c|}{ TSELEBEJ } & TSELEBEJ \\
\hline & LUDLOW & & \multirow{2}{*}{\begin{tabular}{|l|l|} 
GERD"YU & U \\
\cline { 1 - 2 } & $\mathrm{L}$ \\
\end{tabular}} & \multirow{2}{*}{$\begin{array}{l}\text { VELIKAYA } \\
\text { REKA }\end{array}$} & \multirow{2}{*}{$\begin{array}{l}\text { SEVERNYJ } \\
\text { SAVINOBOR }\end{array}$} & SIZIM & \multirow{2}{*}{$\sum \mathrm{BALBAN}_{\mathrm{YU}}$} & SIZIM \\
\hline & \multirow{2}{*}{ WENLOCK } & HOMERIAN & & & & PADIMEJTYVIS $<$ REEF & & PADIMEJTYVIS \\
\hline & & \multirow{3}{*}{ TELYCHIAN } & \multirow{2}{*}{\begin{tabular}{|l|l|} 
SED"EL & U \\
& L \\
\end{tabular}} & \multirow{2}{*}{$\begin{array}{l}\text { BOL'SHOS } \\
\text { NADTEJ }\end{array}$} & \multirow{2}{*}{$\begin{array}{l}\text { YUZHNAYA } \\
\text { PAL'YU }\end{array}$} & \multirow{2}{*}{ VEYAK } & \begin{tabular}{|l|} 
UST'DURNAYU \\
\end{tabular} & UST'DURNAYU \\
\hline & \multirow{4}{*}{$\begin{array}{l}\text { LLAN- } \\
\text { DOVERY }\end{array}$} & & & & & & MARSHRUTNYJ & MARSHRUTNYJ \\
\hline & & & FILIPP"EL' & EL'GORYAKO & \multicolumn{2}{|c|}{ SANDIVEJ } & FILIPP"'EL' & FILIPP"EL' \\
\hline & & AERONIAN & \multirow{2}{*}{ DZHA- } & CHERNAYA REKA & \multirow{2}{*}{\multicolumn{2}{|c|}{ MAKARIKHA }} & LOLASHOR & LOLASHOR \\
\hline & & RHUDDANIAN & & UST'CHERNAYA REKA & & & YARENEJ & YARENEJ \\
\hline \multirow{3}{*}{ 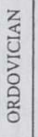 } & \multirow{3}{*}{ ASHGILL } & & \multirow[t]{3}{*}{ SAL'YUKA } & & \multicolumn{2}{|c|}{ SAL'YUKA } & YAPTIKSHOR & YAPTIKSHOR \\
\hline & & & & & ZAPADNYJ TEBUCK & KHOREJVER & 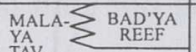 & \\
\hline & & & & & YAGSHOR & MUKER & $\begin{array}{l}\text { TAV- } \\
\text { ROTA }\end{array}$ & \\
\hline
\end{tabular}

Fig. 2. Silurian stratigraphy of the Timan-northern Ural region. L, lower; U, upper.

the stratigraphical scheme of the Northeastern Subregion (Kaljo 1987), the Dzhagal and Filipp"'el' stages correspond to the Llandovery.

\section{Dzhagal Stage}

The Dzhagal Stage is represented by the Yarenej and Lolashor formations in the Subpolar Urals, by the Makarikha Formation in the Khorejver Depression, and by the Ust'Chernaya Reka and Chernaya Reka formations in the northern Timan and the Kanin Peninsula. The up to $300 \mathrm{~m}$ thick Yarenej Formation is characterized by thick-bedded secondary dolostones and rhythmically interbedded dolostones with nodules and burrow structures. Conodonts are rare in the lower part of the formation; in the uppermost beds Oulodus fluegeli (Walliser) and Ctenognathodus coronus (Melnikov) have been recorded (Mel'nikov 1999a). The Makarikha Formation is represented by secondary dolostones and is subdivided into two subformations. The lower subformation is enriched in clastic material and there the conodonts Ozarkodina oldhamensis (Rexroad) and Icriodella stenolophata (Rexroad) are found. Data on sedimentation suggest a hiatus at the base of the Makarikha Formation. The Ust'Chernaya Reka Formation is represented by green, grey, and brown-red dolomitic marlstones, argillites, sandstones, and siltstones. In some sections a bed of conglomerates occurs at the base of the formation. The thickness of the formation in the northern Timan and the Kanin Peninsula reaches $17 \mathrm{~m}$. In the Kanin Peninsula section rare specimens of the conodonts Icriodella sp. indet., Ozarkodina sp., and the vertebrates Logania sp. 1 and Astrospididae are found. The fauna above dates the Yarenej, Ust'Chernaya Reka, and Lower Makarikha formations to the Rhuddanian. 
The Lolashor Formation is subdivided into two subformations. The lower shows a cyclic intercalation of spotty, seminodular, muddy, stipped coralstromatoporoid limestones and secondary dolostones with chert nodules and oriented organic detritus. Rocks of the upper subformation are massive, rich in stromatoporoid-coral fauna, and contain interbeds with Pentamerus. The Chernaya Reka Formation is represented by dark grey and brownish-grey secondary dolostones and dolomitic limestones with stromatoporoids, tabulate corals, pentamerid brachiopods, ostracodes, trilobites, and crinoids. The thickness of this formation is about $30 \mathrm{~m}$. Characteristic of the Lolashor and Chernaya Reka formations are conodonts Pranognathus tenuis (Aldridge) and P. siluricus (Pollock, Rexroad \& Nicoll). In the Upper Makarikha Subformation Distomodus vindemus (Melnikov), a vicarious species of D. kentuckyensis (Rexroad) has been recorded.

The above data allow us to refer the middle and upper parts of the Dzhagal Stage to the Aeronian.

\section{Filipp"el' Stage}

The Filipp"el' Stage is represented by the Filipp"el' Formation in the Subpolar Urals, the Sandivej Formation in the Khorejver Depression, and the El'goryako Formation in the northern Timan and Kanin Peninsula. The Filipp"el' Formation is characterized by widespread alternating stromatolite and stromatoporoid dolostones. The conodonts are represented by an endemic assemblage. The Sandivej Formation consists of brownish-grey secondary dolostones interbedded with light grey sedimentary dolostones containing stromatolites and a clay-silt admixture. The El'goryako Formation is represented mainly by grey and yellow-grey dolomitic limestones and dolostones, sometimes also by argillaceous dolomitic limestones with stromatolites and interbeds of variegated clay, siltstones, sandstones and, occasionally, gypsum. Conodonts are quite numerous and diverse. As in many other regions of the world (e.g. Wales, Canada), they are represented by the species of Icriodella, such as I. malvernensis Aldridge and I. anca Melnikov (a vicarious species of zonal I. inconstans). There are also some finds of Apsidognathus tuberculatus Walliser. That is, the Filipp"el' Stage correlates with the Telychian.

\section{Sed"el' Stage}

The Sed"el' Stage includes the Marshrutnyj and Ust'Durnayu formations in the Subpolar Urals, the Veyak Formation in the Khorejver Depression, and the Bol'shoj Nadtej Formation in the Kanin Peninsula and northern Timan. Commonly, the lower part of this stage is represented by thick-bedded coralstromatoporoid limestones and the upper part by dolostones with laminated algal and stromatolitic beds. The conodont assemblage includes Apsidognathus tuberculatus, rare Pterospathodus n. sp. A Nowlan, and also several species 
of Ozarkodina and Ctenognathodus. Near the top of the Lower Ust'Durnayu Subformation and in the upper part of the Veyak Formation, such characteristic taxa as Apsidognathus tuberculatus and Pterospathodus n. sp. A Nowlan disappear, indicating a Telychian age for the Lower Sed"el' Substage and Sheinwoodian for the Upper Sed"el' Substage.

\section{DATUMS}

The shallow-water shelf environment, with widespread shoal conditions, determined a specific conodont succession in both the Urals and the Northeastern Subregion of the East European Platform. The general characteristics of the conodont faunas of the Timan-northern Ural region are as follows:

(1) a considerably lower frequency of conodonts than in the open sea environment;

(2) taxa with platform elements are found only in the reef and open shelf facies, mainly in the eastern part of the region;

(3) as a rule, the conodont faunas are dominated by "shallow-water" taxa.

The assemblages of Silurian conodonts in the Subpolar Urals include five dominating, morphologically distinct genera: Ozarkodina, Ctenognathodus, Adctenognathodus, Oulodus, Adoulodus (Mel'nikov 1999b) (Fig. 3). In addition

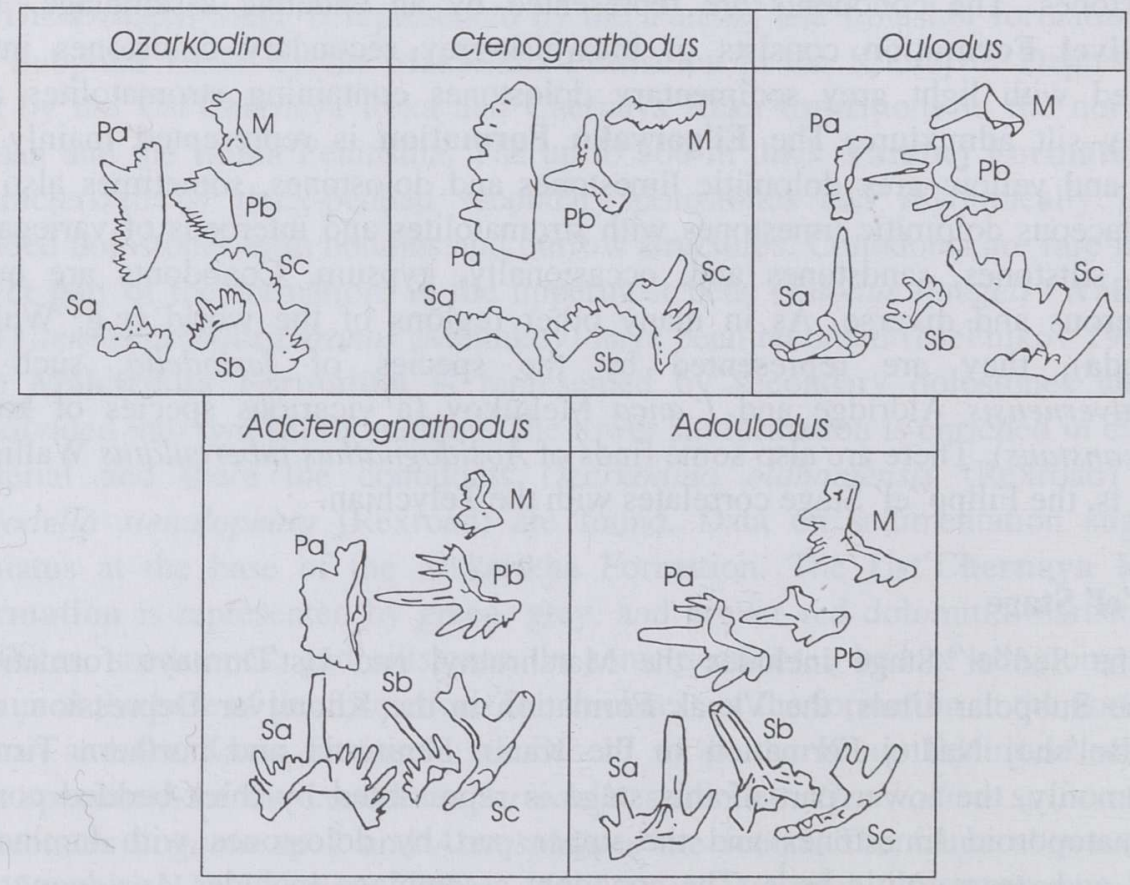

Fig. 3. Shallow-water genera of the Silurian conodonts. 
to the conodont data, in the present paper the distribution of other groups of fauna (Tsyganko \& Chermnykh 1983, 1987) is considered. The analysis of the faunas in the Silurian sequence of the Subpolar Urals (Kozhym River) allowed recognition of 25 datums marked by the appearances and/or disappearances of species (Figs. 4, 5). The datums located less than ten metres away from each other were united into one group to generalize them properly. Evidently, some datums were determined occasionally because of poor sampling, others have limited occurrence.

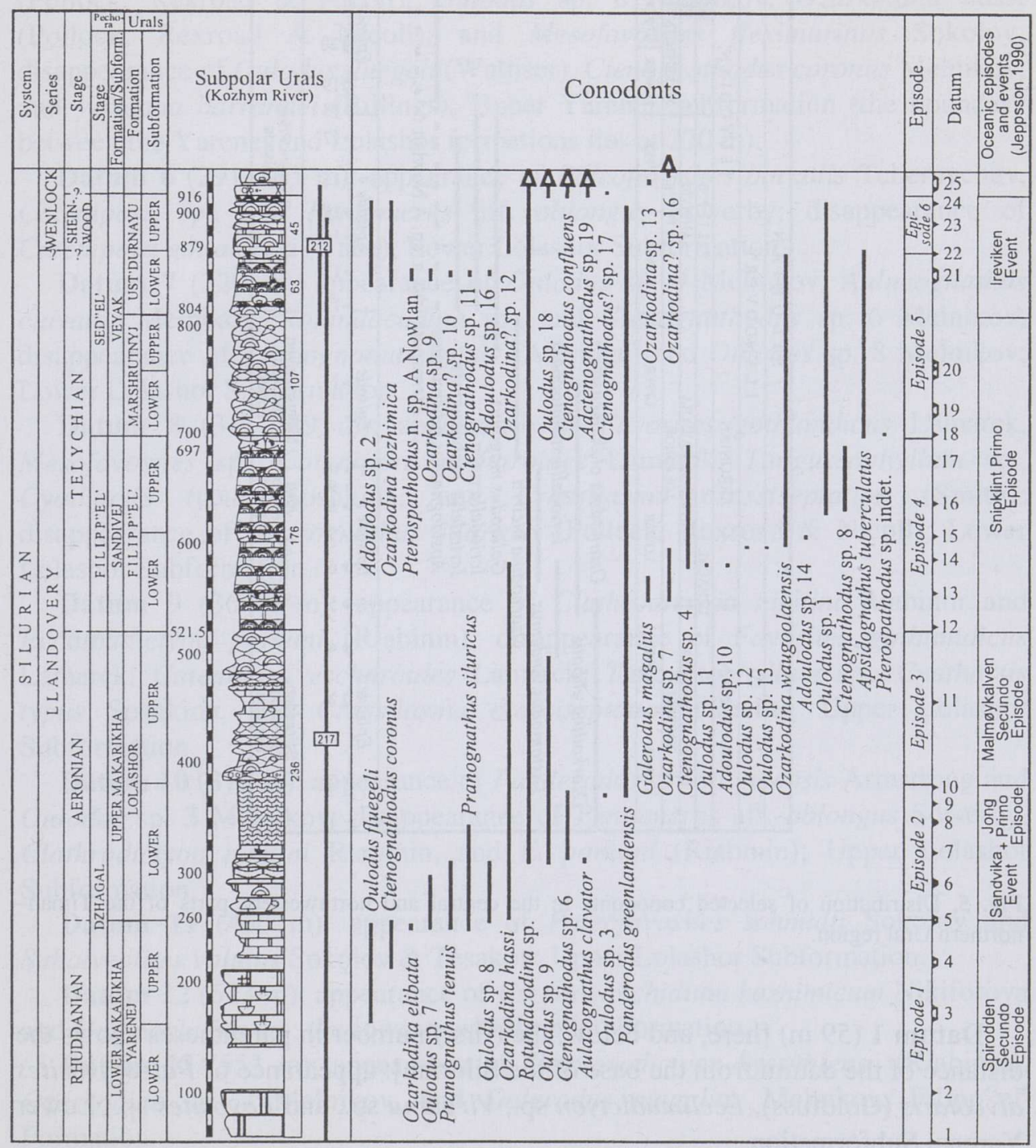

Fig. 4. Distribution of conodonts in the shallow-water deposits of the Subpolar Urals (Kozhym River section). Depth is in metres. For legend see Fig. 6. 


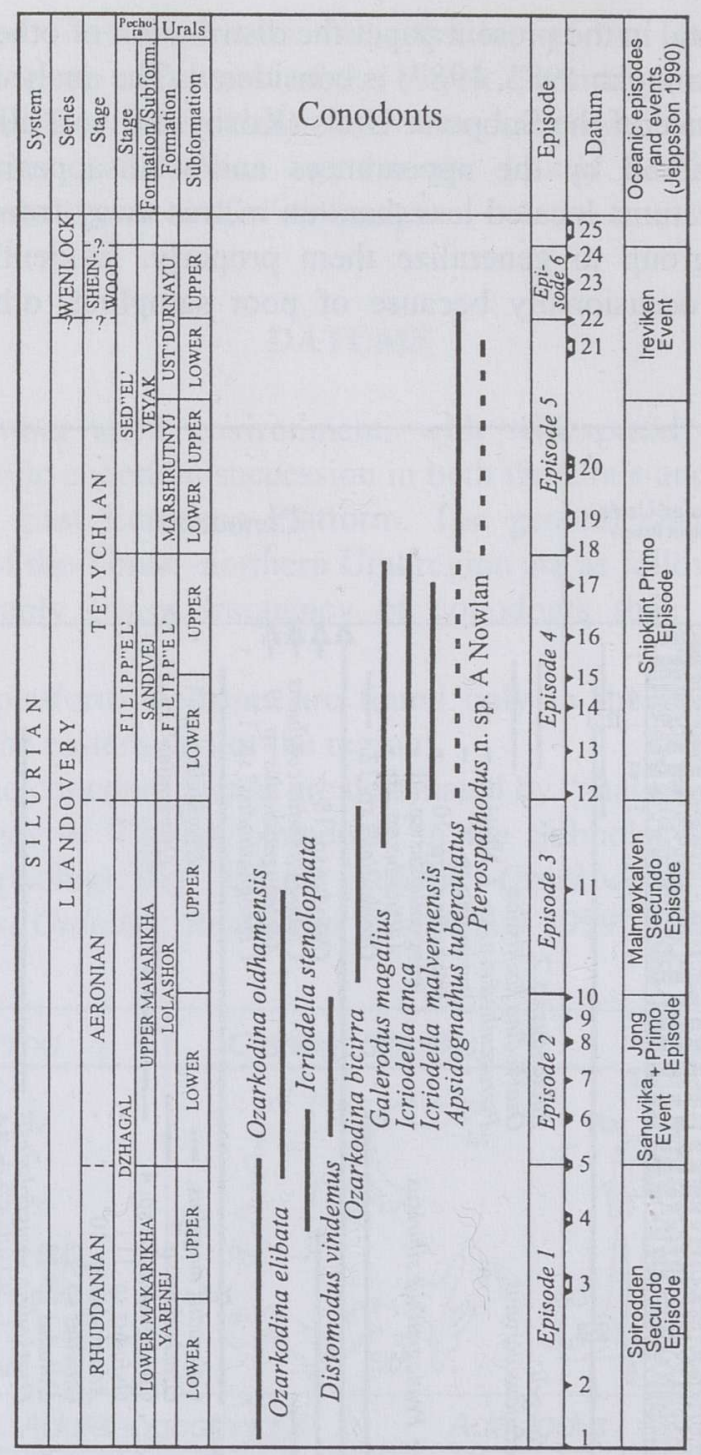

Fig. 5. Distribution of selected conodonts in the central and northwestern parts of the Timannorthern Ural region.

Datum $1(59 \mathrm{~m})$ [here, and below, the (first) number in parentheses shows the distance of the datum from the base of the Silurian]: appearance of Paleofavosites alveolaris (Goldfuss), Ecclimadictyon sp., Virgiana sp., and Favosites sp.; Lower Yarenej Subformation.

Datum 2 (104 m): appearance of Paleofavosites sp. and Catenipora arctica Tchernychev; Lower Yarenej Subformation. 
Datum 3 (172-181 m): appearance of Zygospiraella duboisi (Verneuil) and Oulodus fluegeli (Walliser); the uppermost Lower and the lowermost Upper Yarenej subformations (the boundary between the Lower and Upper Yarenej subformations lies at $166 \mathrm{~m})$.

Datum 4 (219-227 m): appearance of Ctenognathodus coronus Melnikov, Catenipora gotlandica (Yabe), and Virgiana barrandei (Billings); Upper Yarenej Subformation.

Datum 5 (258-262 m): appearance of Ozarkodina elibata (Pollock, Rexroad \& Nicoll), Oulodus sp. 7 Melnikov, Pranognathus tenuis (Aldridge), P. siluricus (Pollock, Rexroad \& Nicoll), Oulodus sp. 8 Melnikov, Ozarkodina hassi (Pollock, Rexroad \& Nicoll), and Mesofavosites fleximurinus Sokolov; disappearance of Oulodus fluegeli (Walliser), Ctenognathodus coronus Melnikov, and Virgiana barrandei (Billings); Upper Yarenej Subformation (the boundary between the Yarenej and Lolashor formations lies at $270 \mathrm{~m}$ ).

Datum 6 (291-295 m): appearance of Paleofavosites borealis Tchernychev, Catenipora sp., and Pentamerus aff. oblongus Sowerby; disappearance of Catenipora gotlandica (Yabe); Lower Lolashor Subformation.

Datum $7(320 \mathrm{~m})$ : appearance of Oulodus sp. 9 Melnikov, Aulacognathus clavator Melnikov, Rotundacodina sp., and Ctenognathodus sp. 6 Melnikov; disappearance of Pranognathus tenuis (Aldridge) and Oulodus sp. 8 Melnikov; Lower Lolashor Subformation.

Datum 8 (347-349 m): appearance of Favosites gothlandicus Lamarck, Mesofavosites sp., Catenipora escharoides Lamarck, Tungussophyllum sp., Cyathactis typus Soshkina, and Crassilasma crassiseptatum (Smith); disappearance of Pranognathus siluricus (Pollock, Rexroad \& Nicoll); Lower Lolashor Subformation.

Datum 9 (364.4 m): appearance of Clathrodictyon nikitini Riabinin and Ecclimadictyon porkuni (Riabinin); disappearance of Favosites gothlandicus Lamarck, Catenipora escharoides Lamarck, Tungussophyllum sp., Cyathactis typus Soshkina, and Crassilasma crassiseptatum (Smith); Upper Lolashor Subformation.

Datum $10(379 \mathrm{~m})$ : appearance of Panderodus greenlandensis Armstrong and Oulodus sp. 3 Melnikov; disappearance of Pentamerus aff. oblongus Sowerby, Clathrodictyon nikitini Riabinin, and E. porkuni (Riabinin); Upper Lolashor Subformation.

Datum 11 (456 m): appearance of Paleofavosites schmidti Sokolov and Subalveolites volutus Sokolov \& Tesakov; Upper Lolashor Subformation.

Datum 12 (523 m): appearance of Pseudoconchidium kozhimicum Nikiforova and Hogmochilina sp.; the lowermost Filipp"el' Formation.

Datum $13(553 \mathrm{~m})$ : appearance of Simplexodictyon kyssuniense (Riabinin), Ozarkodina sp. 7 Melnikov, and Galerodus magalius Melnikov; Filipp"el' Formation.

Datum 14 (583-584 m): appearance of Adoulodus sp. 10, Oulodus sp. 11 Melnikov, and Ctenognathodus sp. 4 Melnikov; Filipp"el' Formation. 
Datum $15(603 \mathrm{~m})$ : appearance of Ozarkodina waugoolaensis Bischoff, Oulodus sp. 12 Melnikov, and Oulodus sp. 13 Melnikov; disappearance of Ozarkodina sp. 7 Melnikov; Filipp"el' Formation.

Datum $16(634 \mathrm{~m})$ : appearance of Oulodus sp. 1 Melnikov and Ctenognathodus sp. 8 Melnikov; Filipp"el' Formation.

Datum $17(671 \mathrm{~m})$ : appearance of Clathrodictyon cylindricum Riabinin and Ecclimadictyon sp.; Filipp"el' Formation.

Datum 18 (707 m): appearance of Apsidognathus tuberculatus Walliser and Pterospathodus sp. indet.; disappearance of Ctenognathodus sp. 4 Melnikov and Ctenognathodus sp. 8 Melnikov; Lower Marshrutnyj Subformation.

Datum 19 (714-722 m): appearance of Favosites forbesi Milne-Edwards \& Haime, Favosites amkardakensis Tchernychev, Multisolenia tortuosa Fritz, and Megalomus sp.; Lower Marshrutnyj Subformation.

Datum 20 (748-762 m): appearance of Ecclimadictyon robustum Nestor, Favosites moyeroensis Sokolov \& Tesakov, Multisolenia uralica Chekhovich, Ecclimadictyon explanatum Bogoyavlenskaya, Neocystiphyllum holtedahli (Wedekind), Multisolenia formosa Sokolov, Angopora sp., Miculiella annae Ivanovsky, Aphyllum sociale Soshkina, and Favosites subformosus Sokolov; Lower Marshrutnyj Subformation.

Datum 21 (834-846 m): appearance of Simplexodictyon podolicum (Yavorsky), Plexodictyon vaigatschensis (Yavorsky), Ozarkodina kozhimica Melnikov, Adoulodus sp. 2 Melnikov, Ozarkodina sp. 9 Melnikov, Pterospathodus n. sp. A Nowlan, Ozarkodina? sp. 10 Melnikov, Ctenognathodus sp. 11 Melnikov, Adoulodus sp. 16 Melnikov, Eukloedenella sp., Parallelostroma typicum (Rosen), Stelodictyon moierense Nestor, Hyattidina sp., and Herrmannina insignis Abushik; Lower Ust'Durnayu Formation.

Datum $22(860 \mathrm{~m})$ : appearance of Simplexodictyon perperum (Riabinin), Columnostroma sp., and Ozarkodina? sp. 12 Melnikov; disappearance of Parallelostroma typicum (Rosen), Stelodictyon moierense Nestor, Hyattidina sp., Herrmannina insignis Abushik, and Apsidognathus tuberculatus Walliser; Lower Ust'Durnayu Formation.

Datum 23 (887 m): appearance of Parastriatopora commutabilis Klaamann and Howellella nordensis (Ljashenko); Upper Ust'Durnayu Subformation.

Datum 24 (903 m): appearance of Eukloedenella grandifabae Abushik, Girvanella sp., Parachaetetes sp., Gibberella pretiosa Abushik, Greenfieldia sp., Eukloedenella kureikiensis Neckaja, and Bingeria? sp.; disappearance of Favosites forbesi Milne-Edwards \& Haime, Oulodus sp. 1 Melnikov, Ozarkodina kozhimica Melnikov, Adoulodus sp. 2 Melnikov, Ozarkodina? sp. 12 Melnikov, and Hyattidina sp.; Upper Ust'Durnayu Subformation.

Datum $25(916-920 \mathrm{~m})$ : appearance of Tollitina minuta (Abushik), Signetopsis bicardinata Abushik, Eoevlanella dizygopleuroides (Abushik), Cyrtherellina inornata (Abushik), Ctenognathodus confluens (Branson \& Mehl), Ctenognathodus sp. 17 Melnikov, Oulodus sp. 18 Melnikov, and Adctenognathodus sp. 19 Melnikov; Lower Gerd"yu Subformation. 
Until recently the Lower Gerd"yu Subformation was referred to the Upper Silurian. The conodont assemblage shows a significant change at the lower boundary of the subformation, but it is mainly represented by poorly studied shallow-water species. At this level Ctenognathodus confluens (Branson \& Mehl) appears. The only well-traced conodont level higher in the sequence is that of the appearance of Polygnathoides siluricus Branson \& Mehl in the Upper Gerd"yu Subformation. This pattern of conodont distribution suggests a Homerian age for the Lower Gerd"yu Subformation and a Ludlow age for the Upper Gerd"yu Subformation.

\section{CYCLICITY AND RELATIVE SEA LEVEL CHANGES}

To analyse the development of the early Silurian sedimentary basin we use the concepts of sequence stratigraphy elaborated by Mitchum (1977), Baum \& Vail (1988), Posamentier \& Vail (1988), and others.

Sequences can be defined as natural successions of layers formed within one eustatic cycle. As a rule sequences are separated from each other by discontinuity surfaces formed during the maximums in relative sea level fall.

Distinct eustatic sea level changes are recorded in the Lower Silurian sections in the studied region. Owing to the existence of shallow-water low-energy environments on most of the Pechora Plate, tidal activity most affected the origin and accretion of sediments. In the Lower Silurian sections, the upwardshallowing elementary cycles (parasequences) predominate, representing the lowenergy shallow-water sub- and supratidal zones. Probably their formation was connected with progradation of the coastal environment over hundreds of kilometres across the shelf.

Six sedimentary sequences have been identified in the Lower Silurian (Fig. 6). All sequences are represented by regular successions of beds (parasequences), bounded by transgressive surfaces.

An idealized parasequence is represented by the following succession of deposits. Carbonate muds with marine benthic fossils at the base of the parasequence gradually become overlain by bioturbated muds lacking organic remains of shallow subtidal, which are followed by stratified sediments of lower and upper intertidal origin. Lower intertidal deposits are represented by bioturbated carbonate muds with large amounts of ostracode remains. The upper intertidal zone contains algal sands where pelloids, well-rounded lithoclasts, oolites, and oncolites dominate. In the upper part of the parasequence there occur supratidal deposits (thin-bedded algal laminites with abundant mud cracks; storm breccias and rudimentary stromatolites) with subaerial sedimentary breccias at the top. The Lower Silurian sections in the Timan-northern Ural region consist of both, complete and reduced parasequences. 


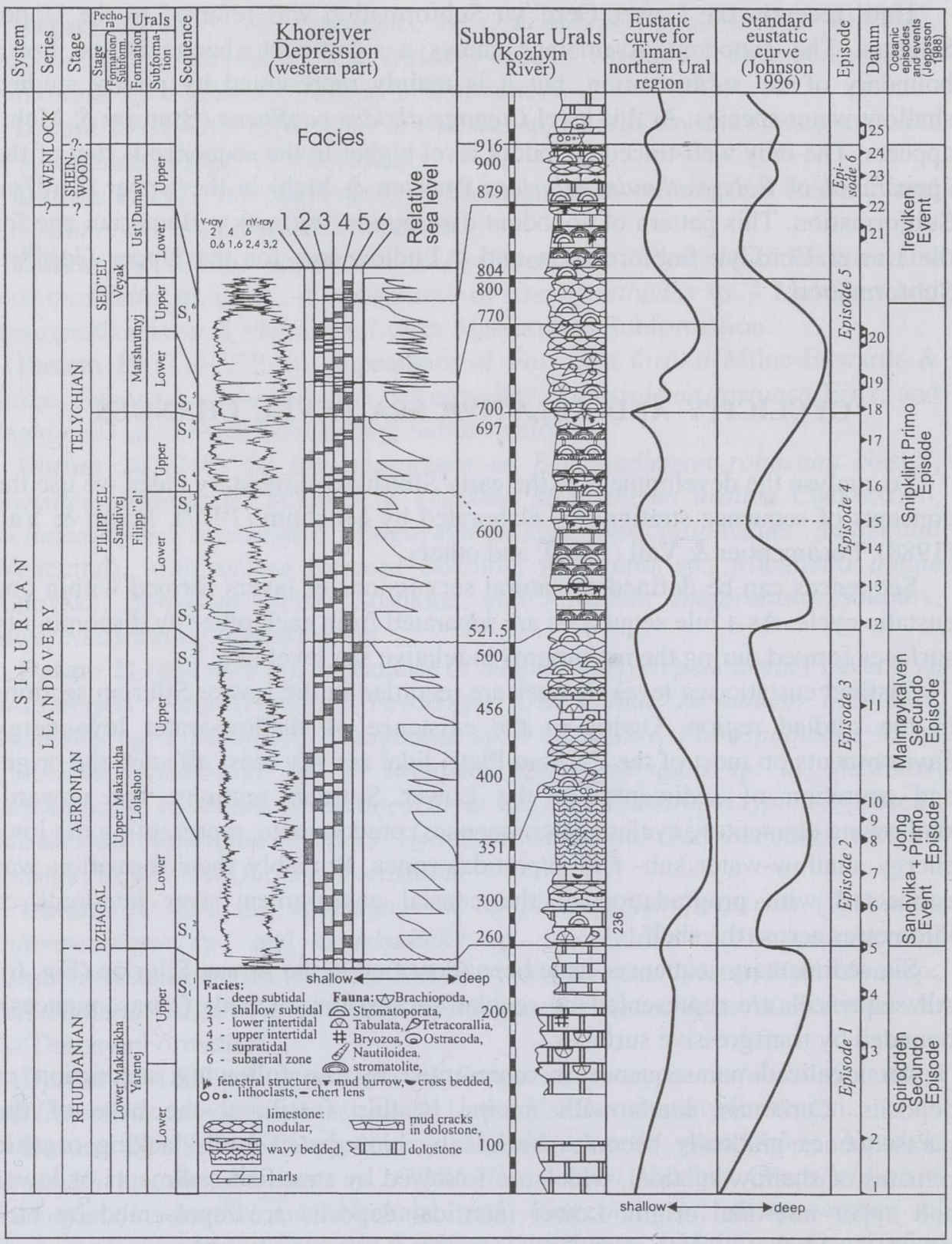

Fig. 6. Sequences and sea level fluctuation in the Early Silurian of the Timan-northern Ural region. Depth is in metres.

Sequence $\mathrm{S}_{1}{ }^{1}$ corresponds to the Lower Makarikha Subformation on the Pechora Plate and to the Yarenej Formation in the Urals. On the Pechora Plate, the elementary cyclicity is traced based on the distribution of carbonate and 
clastic material: carbonate material deposited during the phases of short-term transgressions, clastic material during regressions. The middle part of Sequence $\mathrm{S}_{1}{ }^{1}$ is represented mainly by pure carbonates which evidently formed under the conditions of a maximum highstand in relative sea level. On the Pechora Plate, this sequence is separated from overlying Sequence $S_{1}{ }^{2}$ by an unconformity. This hiatus corresponds to the time of formation of the shallowest-marine - supratidal - facies in the Urals.

Sequence $\mathbf{S}_{1}{ }^{2}$ corresponds to the Upper Makarikha Subformation on the Pechora Plate and to the Lolashor Formation in the Subpolar Urals. The sea level rise at the beginning of late Makarikha time led to the renewal of carbonate sedimentation on the Pechora Plate. During the formation of Sequence $\mathrm{S}_{1}{ }^{2}$, intertidal and supratidal environments dominated in the basin. Twelve parasequences were recognized in this sequence. The lower four are represented by an association of retrogradational deposits and form the Transgressive Systems Tract of the sequence. The base of the fifth parasequence is interpreted as the Maximum Flooding Surface; the overlying ones are treated as corresponding to the Highstand Systems Tract composed of the progradational and aggradational parasequence sets.

Sequence $\mathrm{S}_{1}{ }^{3}$ corresponds to the lower part of the Filipp" ${ }^{\prime \prime} l^{\prime}$ Stage. It consists of six parasequences. Commonly, these parasequences are characterized by shallower-water sediments than those of the Dzhagal Stage. In the parasequences of $\mathrm{S}_{1}{ }^{3}$ the thickness of strata formed in deep subtidal environments is sharply reduced. The parasequences are composed mainly of sediments of the upper intertidal and supratidal facies. The first three parasequences correspond to the Transgressive Systems Tract; the base of parasequence 4 coincides with the Maximum Flooding Surface; the overlying parasequences form the Highstand Systems Tract. The upper boundary of Sequence $\mathrm{S}_{1}{ }^{3}$ is marked by an erosional surface indicating a relative sea level fall during which the deposits were exposed to subaerial denudation.

Sequence $\mathrm{S}_{1}{ }^{4}$ corresponds to the upper part of the Filipp" el' Stage. It consists of four parasequences and is bounded by the discontinuity surfaces which are marked by layers of subaerial clay. The deepest-water sediments occur in the basal part of parasequence 2 and are composed of bioturbated muds formed in the shallow subtidal environment. These types of sediments indicate the rise of relative sea level at the beginning of the cycle and its rather long and stable highstand, followed by a slow fall of sea level. The maximum lowstand of sea level coincides with the boundary between the Filipp"el' and Sed"el' stages. Evidently it caused a short-time stop in the sedimentation during which the strata formed earlier were exposed to subaerial erosion.

The relative sea level fall at the beginning of Filipp"el' time terminated carbonate sedimentation in the western, shallowest-water regions of the basin. At that time the shoal zone of sedimentation migrated to the area of the modern Subpolar Urals. 
Early Sed"el' time was characterized by a rapid transgression and restart of carbonate sedimentation in the Timan-northern Ural region. Three main transgressive-regressive phases in sea level fluctuation are recognized in the Sed"el' Stage.

Sequence $\mathbf{S}_{1}{ }^{5}$ corresponds to the lower part of the Veyak Formation on the Pechora Plate and to the lower part of the Marshrutnyj Formation in the Subpolar Urals. It is characterized by sediments formed in the upper intertidal and supratidal zones.

Sequence $\mathbf{S}_{1}{ }^{6}$ corresponds to the upper part of the Veyak Formation on the Pechora Plate and to the upper part of the Marshrutnyj Formation and the lower part of the Ust'Durnayu Formation in the Subpolar Urals. It consists of nine parasequences. The lower four form the Transgressive Systems Tract - the association of retrogradational sediments. The base of the sixth parasequence is interpreted as the Maximum Flooding Surface at which the transgression was replaced by the regression. The upper five parasequences are characterized by the progradational and aggradational sediments and form the Highstand Systems Tract. Although significant increases in relative sea level occurred during this sedimentary cycle, they did not cause essential deepening of the basin, and the deepest-water sediments in Sequence $S_{1}{ }^{6}$ formed still in shallow-subtidal

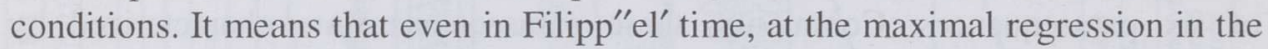
sequence, episodically the sedimentation took place in deeper-water conditions.

\section{SHALLOW SHELF EPISODES}

Analysis of sedimentation and faunas allows distinction of six episodes in the evolution of the Timan-northern Ural basin. Each episode reflects a certain cycle in the sequence of relative sea level changes and is characterized by a specific assemblage of fauna and a sequence of biotic events - appearance or disappearance of taxa.

Episode 1 corresponds to the Rhuddanian (lower part of the Dzhagal Stage, Figs. 4-6). It is characterized by a lowstand of relative sea level and includes datums 1-4. Ozarkodina oldhamensis is present in the supratidal sediments in the central part of the basin. The end of the episode was marked by an abrupt sea level fall. The major part of the Pechora Plate was exposed and the carbonate sedimentation continued only in the eastern parts of the region. The Yarenej Stage is represented by supratidal sediments coeval with the hiatuses fixed in the central part of the Pechora Plate. The northern part of the basin (Kanin Peninsula, Fig. 1) is represented by the clastic deposits with indeterminate conodonts of Icriodella type. Ozarkodina oldhamensis is the guide species for oceanic Spirodden Secundo Episode (Aldridge et al. 1993). These data suggest that Episode 1 corresponds to the Spirodden Secundo Episode. 
The beginning of Episode 2 coincides with a significant rise in relative sea level. This episode was characterized by the maximum in the progradation of rather deep-water conditions to the shelf of the Timan-northern Ural basin during the early Palaeozoic. Datums 5-10 are recognized in this interval. These deposits correspond to the middle part of the Dzhagal Stage. Conodont assemblages with Distomodus vindemus (shallow-water analogue of D. kentuckyensis) and Icriodella stenolophata occur in deep subtidal facies of the central areas of the region. Characteristic of the open-shelf sediments in the Urals and Kanin Peninsula are Pranognathus tenuis, P. siluricus, and rare Distomodus kentuckyensis. P. tenuis determines the lower boundary of the Jong Primo Episode (Aldridge et al. 1993). Accordingly, the occurrence of P. tenuis correlates the strata formed during Episode 2 with the Jong Primo Episode (lower Aeronian).

During Episode 3 the Highstand Systems Tract of Sequence $S_{1}{ }^{2}$, reflecting a gradual fall in relative sea level, was formed. The maximum of the relative sea level fall led to subaerial drainage of the major part of the Pechora Plate and marked the end of the episode. Episode 3 includes datum 11 and is probably related to the Malmøykalven Secundo Episode (upper Aeronian).

Episode 4 consists of two cycles during which two Late Llandovery (Telychian) sequences formed. This episode corresponds to the Filipp"el' Stage and is characterized by a general fall in relative sea level. It includes datums 12-17. The Pterospathodus assemblage is absent in these deposits. In the central and northern parts of the region conodonts are represented by the vicarious species of the Icriodella inconstans assemblage. In the Subpolar Urals, various conodont assemblages including Ozarkodina, Oulodus, Ctenognathodus and related genera are found. Unfortunately, Pterospathodus celloni, the guide species for the Snipklint Primo Episode has not been found in the deposits of the Timannorthern Ural region, but Aldridge (Aldridge et al. 1993) has mentioned an Icriodella assemblage which spread over the shallow basins of the world (England, Wales, Anticosti) during the late part of this oceanic episode. The find of such assemblage allows correlation of Episode 4 with the Snipklint Primo Episode.

Episode 5 represents one eustatic cycle which is characterized by an abrupt relative sea level rise at the beginning and fall at the end of the cycle. The episode includes datums 18-22. The occurrence here of Apsidognathus and comparison of the Timan-northern Ural sea level curve with the standard one elaborated by Johnson (1996) date this episode to the Telychian.

Episode 6 (Lower Sheinwoodian) is characterized by a general fall in relative sea level, which corresponds to late Ust'Durnayu time. It includes datums 23-24.

Episodes 5 and 6 are time equivalents of the Sed"el' Stage. The conodont assemblage represented by Apsidognathus tuberculatus, shallow-water species of Ozarkodina, Oulodus, Ctenognathodus, and very rare Pterospathodus n. sp. A Nowlan spreads all over the region. Although the diversity of the species in the Timan-northern Ural region is not as great as in other basins of the world, the 
assemblage of conodonts is rather stable, which allows us to recognize here some datums described by Aldridge et al. (1993), e.g. Datum 2 of the Ireviken Event (= the level of the disappearance of Apsidognathus). We may also conclude that the Upper Sed"el' Substage (Ust'Durnayu Formation and-synchronous Upper Veyak Subformation) corresponds to the Ireviken Event, or to its upper part.

\section{CONCLUSIONS}

The study of sedimentary features in the Early Silurian of the Timan-northern Ural region has shown that Early Makarikha time was dominated by carbonate ooze sedimentation under transgressive conditions. Maximum flooding and deeper-water carbonate sedimentation occurred in the middle of Makarikha time when rapid and extensive transgression caused the expansion of the shelf environment westward and the deposition of deep-water argillaceous-siliciouscarbonate ooze on the modern western slope of the Urals. Further, accumulation of sediments took place under highstand conditions. In the middle of Makarikha time a prominent shift in the conditions of sedimentation took place: the transgressive trend in the evolution of the basin changed to a regressive one.

Sandivej time was characterized by a distinct sea level fluctuation which caused the formation of several small-scale sequences showing evident transgressive, maximum flooding, and highstand phases. In Sed"el' time, the extent of the transgression was the same as in the Early Dzhagal. At the same time, the sea level rise was evidently not so significant and in the parasequences of both the western and eastern parts of the region the intertidal facies prevailed. The maximums in sea level rise are represented by shallow subtidal deposits.

The correlation of the Early Silurian climatic episodes (Jeppsson 1988) with shallow shelf episodes recognized in the Timan-northern Ural region shows their considerable conformity. This confirms the suggestion that both the climatic changes and sea level fluctuation, influencing the development of a shallow basin, have the general reasons obviously connected with the phases of Plate activity.

The conformity of episodes allows dating the age of regional stages: Lower Dzhagal Substage as Rhuddanian, Upper Dzhagal Substage as Aeronian, Filipp"el' Stage and Lower Sed"el' Substage as Telychian. The Upper Sed"el' Substage appears to be Seinwoodian in age.

\section{ACKNOWLEDGEMENTS}

The manuscript was much improved following the discussions with P. Männik and the comments of the reviewers D. Kaljo and H. Nestor. 


\section{REFERENCES}

Aldridge, R. J., Jeppsson, L. \& Dorning, K. J. 1993. Early Silurian oceanic episodes and events. J. Geol. Soc. London, 150, 501-513.

Baum, G. R. \& Vail, P. R. 1988. Sequence stratigraphic concepts applied to Paleogene outcrops, Gulf and Atlantic basins. In Sea-level Changes: an Integrated Approach (Wilgus, C. K., Hastings, B. S., Kendall, C. G. St. C., Posamentier, H. W., Ross, C. A. \& Van Wagoner, J. C., eds.). SEPM Spec. Publ., 42, 309-328.

Jeppsson, L. 1988. Towards an oceanic model for Silurian lithologic and faunistic changes. Courier Forschungsinst. Senckenberg, 102, 242.

Jeppsson, L. 1990. An oceanic model for lithological and faunal changes, tested on the Silurian record. J. Geol. Soc. London, 147, 663-674.

Jeppsson, L. 1994. The anatomy of the mid-Early Silurian Ireviken Event. In Paleontological Event Horizons: Ecological and Evolutionary Implications (Brett, C., ed.), pp. 451-492. Columbia Univ. Pr., New York.

Jeppsson, L., Aldridge, R. J. \& Dorning, K. J. 1995. Wenlock (Silurian) oceanic episodes and events. J. Geol. Soc. London, 152, 487-498.

Johnson, M. E. 1996. Stable cratonic sequence and standard for Silurian eustasy. In Paleozoic Sequence Stratigraphy: Views from the North American Craton (Witzke, B. J., Ludvigsson, G. A. \& Day, J. E., eds.). Geol. Soc. Am. Spec. Pap., 306, 203-211

Kaljo, D. L. (ed.). 1987. Resheniya mezhvedomstvennogo stratigraficheskogo soveshchaniya po ordoviku i siluru Vostochno-Evropejskoj platformy $1984 \mathrm{~g}$. s regional'nymi stratigraficheskimi skhemami. Izd. VSEGEI, Leningrad (in Russian).

Mel'nikov, S. V. 1999a. Conodonts of the Ordovician and Silurian of the Timan-North Ural Region. Izd. VSEGEI, St. Petersburg (in Russian).

Mel'nikov, S. V. 1999b. Silurian shallow-water conodonts in the type section of Subpolar Urals (Kozhym River). In Geologiya i mineral'nye resursy evropejskogo severo-vostoka Rossii: novye rezul'taty $i$ novye perspektivy. Materialy XIII Geologicheskogo s"ezda Respubliki Komi, Vol. II (Yushkin, N. P., ed.), pp. 277-280. Inst. geol. Komi nauch. tsentra UrO RAN, Syktyvkar (in Russian).

Mel'nikov, S. V. \& Zhemchugova, V. A. 1999. Lower Silurian of the Timan-North Ural region (problems of global correlation). In Neftegazovaya geologiya na rubezhe vekov... Doklady yubilejnoj konferentsii 70 let VNIGRI, 3: Stratigrafiya, obshchaya geologiya, regional'nyj prognoz (Belonin, M. D., ed.), pp. 143-151. VNIGRI, St. Petersburg (in Russian).

Mitchum, P. M. 1977. Seismic stratigraphy and global changes of sea level. Part 1: Glossary of terms used in seismic stratigraphy. In Seismic Stratigraphy Applications to Hydrocarbon Exploration (Payton, C. E., ed.). AAPG Mem., 26, 205-212.

Nesov, L. A. 1990. Influence of the water circulation in ocean and liman-lagoonal basins on the sedimentational regime and fossil preservation. In Predely tochnosti biostratigraficheskoj korrelyatsii: Tezisy dokl. XXXVI sessii VPO, pp. 54-55. Syktyvkar (in Russian).

Posamentier, H. W. \& Vail, P. R. 1988. Eustatic controls on clastic deposition II - sequence and systems tract models. In Sea-level Changes: an Integrated Approach (Wilgus, C. K., Hastings, B. S., Kendall, C. G. St. C., Posamentier, H. W., Ross, C. A. \& Van Wagoner, J. C., eds.). SEPM Spec. Publ., 42, 125-154.

Tsyganko, V.S. \& Chermnykh, V. A. (eds.). 1983. Opornye razrezy pogranichnykh otlozhenij silura $i$ devona Pripolyarnogo Urala. Inst. geol. Komi filiala Akad. nauk SSSR, Syktyvkar (in Russian).

Tsyganko, V. S. \& Chermnykh, V. A. (eds.). 1987. Opornye razrezy verkhnego ordovika i nizhnego silura Pripolyarnogo Urala. Inst. geol. Komi filiala Akad. nauk SSSR, Syktyvkar (in Russian). 


\title{
ALAMSILURI STRATIGRAAFIA TIMAANI-UURALI PÕHJAOSA REGIOONIS NING EUSTAATILINE FLUKTUATSIOON
}

\author{
Sergei MELNIKOV ja Valentina ŽEMTŠUGOVA
}

Timaani-Uurali põhjaosa siluri läbilõiget on püütud korreleerida rahvusvahelise stratigraafilise skaalaga ja kõrvutada mõnede globaalsete kliimasündmustega. Siluri tugiläbilõikes Lähispolaar-Uuralis esineva fauna leviku uurimise tulemused võimaldasid fikseerida 25 taset, millel toimusid olulised muutused faunas. Järjendstratigraafilise analüüsi tulemusel eristati regiooni alamsiluris kuus üksust. Kogutud paleontoloogiliste ja järjendstratigraafiliste andmete põhjal on välja eraldatud madalaveelise šelfibasseini arengu etapid, mis on seotud meretaseme eustaatiliste kõikumistega. Uuringud näitasid madalaveeliste episoodide kokkulangevust L. Jeppssoni (1990) kirjeldatud globaalsete ookeaniliste episoodidega. See kokkulangevus osutab mõlemat tüüpi episoodide puhul ühisele liikumapanevale jõule, mis meie arvates on seotud maakoore tektoonilise aktiivsuse etappidega. Tuginedes meie poolt eristatud madalaveeliste episoodide ja ookeaniliste episoodide kokkulangevusele võib järeldada, et Alam-Džagali alamlade vastab globaalsel stratigraafilisel skaalal Rhuddanile, Ülem-Džagali alamlade aga Aeronile. Filippjeli lade ja varem Wenlocki-ealiseks peetud AlamSedjeli alamlade korreleeruvad Telychiga, Ülem-Sedjeli alamlade aga tõenäoliselt Sheinwoodiga.

\section{СТРАТИГРАФИЯ НИЖНЕГО СИЛУРА ТИМАНО- СЕВЕРОУРАЛЬСКОГО РЕГИОНА И ЭВСТАТИЧЕСКИЕ КОЛЕБАНИЯ УРОВНЯ МОРЯ}

\author{
Сергей В. МЕЛЬНИКОВ и Валентина А. ЖЕМЧУГОВА
}

Предпринята попытка сопоставить разрез силура Тимано-Североуральского региона с международной стратиграфической шкалой и $\mathrm{c}$ некоторыми глобальными климатическими событиями. В результате изучения распределения фауны в опорном разрезе нижнего силура Приполярного Урала выделено 25 уровней, отмеченных появлением и/или исчезновением таксонов. Секвенстратиграфический анализ позволил установить в нижнесилурийских отложениях 6 секвенций. По совокупности секвенстратиграфических и палеонтологических данных выделены этапы (эпизоды) развития мелководного шельфового бассейна, связанные с эвстатическими колебаниями уровня моря. Исследования показали соответствие мелководных эпизодов с океаническими, глобальными 
эпизодами (Jeppsson 1990), что свидетельствует об общих побуждающих причинах, связанных с этапами активности тектоники плит. Установленное соответствие позволило определить возраст нижнеджагалского подгоризонта региона как рудданиан, верхнеджагалского - как аэрониан. Филиппъельский горизонт и ранее относимый к венлоку нижнеседъельский подгоризонт соответствуют теличию, а верхнеседъельский подгоризонт, вероятно, - шейнвуду. 